\title{
Exercise and Structure Improve Juvenile Chinook Salmon Rearing Performance
}

\author{
Jill M. Voorhees, Nathan Huysman, Eric Krebs, Michael E. Barnes \\ South Dakota Department of Game, Fish and Parks, McNenny State Fish Hatchery, Spearfish, SD, USA \\ Email: jill.voorhees@state.sd.us
}

How to cite this paper: Voorhees, J.M., Huysman, N., Krebs, E. and Barnes, M.E. (2021) Exercise and Structure Improve Juvenile Chinook Salmon Rearing Performance. Open Journal of Marine Science, 11, 80-91. https://doi.org/10.4236/ojms.2021.112006

Received: March 9, 2021

Accepted: April 22, 2021

Published: April 25, 2021

Copyright $\odot 2021$ by author(s) and Scientific Research Publishing Inc. This work is licensed under the Creative Commons Attribution International License (CC BY 4.0).

http://creativecommons.org/licenses/by/4.0/

\begin{abstract}
This experiment evaluated the use of an exercise routine and vertically-suspended structure during juvenile landlocked fall Chinook salmon (Oncorhynchus tshawytscha; mean \pm SE, initial weight $1.47 \pm 0.03 \mathrm{~g}$, total length $56.4 \pm$ $0.4 \mathrm{~mm}$ ) rearing. Four treatments were used: 1) no exercise routine nor vertically-suspended structure, 2) exercise and structure, 3) exercise and no structure, and 4) no exercise and structure. Water velocities in tanks without exercise were $12 \mathrm{~cm} / \mathrm{s}$, where-as the exercise routine consisted of seven days at 12 $\mathrm{cm} / \mathrm{s}$ followed by seven days at $18 \mathrm{~cm} / \mathrm{s}$. The structure was an array consisting of four vertically-suspended aluminum angles. Total tank gain and percent gain were significantly greater after 50 days in the tanks of salmon subjected to the exercise routine and structure compared to the three other treatments. Gain and percent gain were also significantly greater in the tanks receiving structure without exercise compared to tanks with exercise and no structure or tanks with neither exercise nor structure. Feed conversion ratio was significantly improved in the salmon tanks with structure and without exercise compared to all other treatments. There were no significant differences for individual fish weight, total length, specific growth rate, or condition factor among any of the treatments at the end of the experiment. These results indicate that the use of both an exercise routine and vertically-suspended structure may be beneficial during the rearing of juvenile landlocked fall Chinook salmon.
\end{abstract}

\section{Keywords}

Environmental Enrichment, Salmonid, Oncorhynchus tshawytscha, Vertically-Suspended

\section{Introduction}

Exercise and structure are both forms of environmental enrichment during hat- 
chery rearing. The benefits of using either on fish growth have been well documented. In particular, exercise has been shown to increase growth [1] [2] [3] [4], swimming performance [1] [5], disease resistance [4] [6], and post-stocking survival [7]. In addition, exercise decreases stress levels [8], stress recovery time [9] [10] [11], and agonistic behavior [12] [13]. Structural enrichment has produced similar benefits [14] [15].

While fish in circular tanks can be easily exercised by simply adjusting in-tank radial velocities, the addition of structure has been varied and complex. Parts of trees [16] [17] [18] [19] [20], cobble [19] [21] [22] [23], artificial plant material [24] [25] [26] [27] [28], concrete blocks [29], and polyvinyl chloride [17] [27] [28] [30] [31] [32] have all been added to hatchery rearing tanks. Although many of these structures have produced positive results, they are not practical on a production scale because the addition of these structures impedes the hydraulic selfcleaning nature of circular tanks, dramatically increasing tank cleaning labor and the possibility of disease outbreaks [29] [33] [34].

To retain the inherent self-cleaning of circular tanks and also provide in-tank enrichment, Kientz and Barnes [35] developed vertically-suspended structure. Kientz and Barnes [35] observed hatchery rearing improvements associated with the vertical-suspension of an aluminum rod array. Subsequent experiments with suspended strings of spheres, aluminum angles, and plastic conduit produced similar benefits during the rearing of salmonids [15] [35]-[41]. However, positive results from vertically-suspended structure were not observed by White et al. [42], Huysman et al. [43], and Jones et al. [44]. Because these structures are vertically-suspended they do not interfere with the self-cleaning nature of circular tanks like the other structures discussed do.

Little research has been done evaluating the potential impacts of using both exercise and structure. These experiments have all used juvenile rainbow trout (Oncorhynchus mykiss) and the results have been inconsistent. Voorhees et al. [45] noted a significant interaction between exercise and vertically-suspended structure on trout rearing performance. In contrast, Voorhees et al. [46] reported no such interaction, stating that each form of environmental enrichment is likely acting independently. This study was undertaken to provide more clarity into the possible combined effects of both an exercise regime and vertically-suspended structure. In addition, juvenile fall Chinook salmon (Oncorhynchus tshawytscha) were used to expand the knowledge base beyond rainbow trout.

\section{Methods}

This study occurred at McNenny State Fish Hatchery, rural Spearfish, South Dakota, USA, using degassed and aerated well-water $\left(11^{\circ} \mathrm{C}\right.$; total hardness as $\mathrm{CaCO}_{3}, 360 \mathrm{mg} / \mathrm{L}$; alkalinity as $\mathrm{CaCO}_{3}, 210 \mathrm{mg} / \mathrm{L} ; \mathrm{pH}, 7.6$; total dissolved solids, $390 \mathrm{mg} / \mathrm{L}$ ). Juvenile Chinook salmon (mean \pm SE, length: $56.4 \pm 0.4 \mathrm{~mm}$, weight: $1.47 \pm 0.03 \mathrm{~g}, n=110)$ were reared in twelve circular tanks $(1.8 \mathrm{~m}$ diameter $\times 0.6$ 
$\mathrm{m}$ deep; $0.4 \mathrm{~m}$ water depth). Approximately 10,000 fish (14.7 kg) were placed into each tank on February 6, 2019. This study lasted for 50 days.

Four treatments ( $n=3)$ were used: 1$)$ no routine exercise nor vertically-suspended structure (control), 2) both an exercise routine and structure, 3) exercise routine and no structure, and 4) no exercise routine and structure. Water velocities in tanks without exercise were $12 \mathrm{~cm} / \mathrm{s}$, where-as the exercise routine consisted of alternating seven days at $12 \mathrm{~cm} / \mathrm{s}$ followed by seven days at $18 \mathrm{~cm} / \mathrm{s}$. Velocities were measured directly behind the spray bar at a depth of $0.2 \mathrm{~m}$ (halfway in water column) using a flowmeter (JDC Electronics Flowatch Flowmeter, JDC, Yverdon-les-Bains, Switzerland). Tank velocities were adjusted by adjusting the angle of the spray bars, and water flows were kept constant throughout the study. All tanks, regardless of treatment, were almost fully covered with corrugated plastic as described by Walker et al. [47]. The vertically-suspended structure used was an array of four aluminum angles suspended through the corrugated-plastic covers as described by Krebs et al. [36].

Feed was projected using the hatchery constant method [48] with an expected feed conversion ratio of 1.1. The feeding rates used were at or slightly above satiation and varied between the exercise and non-exercise treatments [49]. Tanks of fish not subjected to the exercise routine were fed for a projected growth rate of $0.065 \mathrm{~cm} /$ day, while exercised fish were fed for a projected growth rate of 0.75 $\mathrm{cm} /$ day.

At the end of the experiment ten fish from every tank were individually weighed to the nearest $1.0 \mathrm{~g}$ and measured (total length) to the nearest $1.0 \mathrm{~mm}$, and the total biomass of each tank was weighed to the nearest $0.05 \mathrm{~kg}$. The following equations were used:

$$
\begin{gathered}
\text { Gain }=\text { end weight }- \text { start weight } \\
\text { Gain }(\%)=100 * \text { gain } /(\text { start weight }) \\
\text { Feed Conversion Ratio }(\text { FCR })=(\text { food fed }) / \text { gain } \\
\text { Specific Growth Rate }(\text { SGR }) \\
=100 *[(\ln (\text { end weight })-\ln (\text { start weight })) /(\text { number of days })] \\
\text { Condition Factor }(\mathrm{K})=10^{5} *(\text { fish weight }) /[\text { fish length }]^{3}
\end{gathered}
$$

One-way Analysis of Variance (ANOVA) was used to analyze the data with SPSS (24.0) statistical program (IBM, Armonk, New York, USA). Because the tanks were the experimental units, and not the individual fish, nested ANOVA was conducted on individual fish data. If the ANOVA indicated significant differences, Fisher's Protected Least Significant Difference procedure was used for pair-wise comparisons. Significance was pre-determined at $P<0.05$.

\section{Results}

Final tank weight, gain, and percent gain were all significantly greater in the tanks of fish receiving both an exercise routine and structure compared to all 
other treatments (Table 1). Gain and percent gain were also significantly greater in the tanks receiving structure without exercise compared to tanks with exercise and no structure or tanks with neither exercise nor structure. Feed conversion ratio was significantly better in the unexercised tanks with structure (mean $\pm \mathrm{SE}$; $1.02 \pm 0.01)$, compared to unexercised and unstructured tanks $(1.15 \pm 0.03)$ which was similar to routine exercise with structure $(1.18 \pm 0.03)$. The tanks on routine exercise without structure were significantly poorer than all other treatments $(1.45 \pm 0.01)$. Percent mortality was relatively minor and not significantly different among the treatments.

There were no significant differences in individual fish length, weight, specific growth rate, or condition factor among any of the treatments (Table 2). Specific growth rates were similar among the treatments, ranging from $2.90 \pm 0.08$ (mean $\pm \mathrm{SE}$ ) in the fish receiving the exercise routine without structure to $3.04 \pm 0.04$ in the fish receiving both exercise and structure.

\section{Discussion}

The results of this study indicate that using two forms of environmental enrichment in combination can have positive effects during fish rearing. These results with Chinook salmon support those obtained by Voorhees et al. [45] with rainbow trout subjected to continual exercise. However, Voorhees et al. [46] reported no benefits of combining both exercise and structure during juvenile

Table 1. Mean \pm SE final tank weight, gain, percent gain, food fed, feed conversion ratio $\left(\mathrm{FCR}^{\mathrm{a}}\right)$, and percent mortality of Chinook salmon reared with or without vertically-suspended structure and with or without routine exercise. Means with different letters in the same row differ significantly $(p<0.05 ; n=3)$.

\begin{tabular}{|c|c|c|c|c|c|c|c|c|c|c|c|c|c|}
\hline \multirow[b]{2}{*}{ Tank weight $(\mathrm{kg})$} & \multicolumn{3}{|c|}{ Control } & \multicolumn{3}{|c|}{ Exercise } & \multicolumn{3}{|c|}{ Structure } & \multicolumn{3}{|c|}{ Combination } & \multirow{2}{*}{$\begin{array}{c}P \text {-value } \\
0.000\end{array}$} \\
\hline & 55.7 & \pm & $1.1 \mathrm{x}$ & 55.0 & \pm & $0.3 \mathrm{x}$ & 60.7 & \pm & $0.4 \mathrm{y}$ & 64.1 & \pm & $1.1 \mathrm{z}$ & \\
\hline Gain (kg) & 41.0 & \pm & $1.1 \mathrm{x}$ & 40.3 & \pm & $0.3 \mathrm{x}$ & 46.0 & \pm & $0.4 \mathrm{y}$ & 49.4 & \pm & $1.1 \mathrm{z}$ & 0.000 \\
\hline Gain (\%) & 278.7 & \pm & $7.8 \mathrm{x}$ & 274.2 & \pm & $2.0 \mathrm{x}$ & 312.9 & \pm & $2.6 \mathrm{y}$ & 336.0 & \pm & $7.7 \mathrm{z}$ & 0.000 \\
\hline FCR & 1.15 & \pm & $0.03 \mathrm{y}$ & 1.45 & \pm & $0.01 \mathrm{x}$ & 1.02 & \pm & $0.01 \mathrm{z}$ & 1.18 & \pm & $0.03 \mathrm{y}$ & 0.000 \\
\hline Mortality (\%) & 0.6 & \pm & 0.1 & 0.8 & \pm & 0.1 & 1.6 & \pm & 0.5 & 0.9 & \pm & 0.1 & 0.124 \\
\hline
\end{tabular}

Table 2. Individual mean \pm SE total length, weight, specific growth rate (SGR ${ }^{a}$ ), and condition factor $\left(\mathrm{K}^{\mathrm{b}}\right)$ of Chinook salmon reared with or without vertically-suspended structure and with or without routine exercise $(n=3)$.

\begin{tabular}{cccccccccccccc}
\hline & \multicolumn{3}{c}{ Control } & \multicolumn{3}{c}{ Exercise } & \multicolumn{2}{c}{ Structure } & \multicolumn{2}{c}{ Combination } & $P$-value \\
\hline Length $(\mathrm{mm})$ & 87.5 & \pm & 0.2 & 87.1 & \pm & 0.8 & 87.4 & \pm & 1.7 & 87.9 & \pm & 0.9 & 0.957 \\
Weight $(\mathrm{g})$ & 7 & \pm & 0 & 6 & \pm & 0 & 6 & \pm & 0 & 7 & \pm & 0 & 0.695 \\
SGR & 3.01 & \pm & 0.08 & 2.9 & \pm & 0.08 & 2.98 & \pm & 0.11 & 3.04 & \pm & 0.04 & 0.681 \\
K & 0.98 & \pm & 0.03 & 0.94 & \pm & 0.01 & 0.97 & \pm & 0.02 & 0.98 & \pm & 0.01 & 0.574 \\
\hline
\end{tabular}

${ }^{\mathrm{a}} \mathrm{SGR}=100 *(\ln ($ end weight $)-\ln ($ start weight $)) /($ number of days $) .{ }^{\mathrm{b}} \mathrm{K}=10^{5 *}$ (fish weight $) /(\text { fish length })^{3}$. 
rainbow trout rearing. The Voorhees et al. [46] study lasted 109 days, and final tank weights were likely excessive. As suggested by Huysman et al. [43], density-dependent growth rates may have hindered the ability to detect significant differences in the Voorhees et al. [46] experiment. Of course, there may be speciesspecific differences in response to environmental enrichment [14].

The intermittent exercise routine used in this study was designed to prevent exercise fatigue [50] [51]. Although a combination of both exercise and structure led to rearing improvements in this study, the lack of effect of exercise alone on Chinook salmon growth is not unexpected. Davison [52] indicated that Chinook salmon do not benefit from exercise and Parker and Barnes [53] reported similar growth between exercised and non-exercised Chinook salmon. Kiessling et al. [54] and Gallaugher et al. [12] observed decreased growth in exercised Chinook salmon. In other fish species, exercise has been shown to generally increase growth [1] [4] [6] [11] [50] [55]-[61], though this is not always the case [8] [13] [54].

The duration of this study was typical for other experiments evaluating intermittent exercise routines [2] [4] [6] [11] [12], as well as those using continuous exercise [1] [9] [13] [35] [49] [57] [62] [63]. The velocities used in this experiment correspond to approximately 2 to 3 body lengths/sec at the start and 1.5 to 2 body lengths/sec at the end, both of which are slightly faster than the 0.5 to 1.7 body lengths/sec suggested by McKenzie et al. [64]. However, these velocities were taken prior to structure and fish being added to tanks. Vertically-suspended structure radically changes and typically decreases circular tank water velocities [65] [66] [67], and the presence of fish alter velocity profiles as well [67] [68]. It is possible that the positive effect on gain observed in the tanks receiving both exercise and structure, in comparison to the lack of effect of just exercise, could be due to the water velocity changes caused by the aluminum angle array [35].

Similar to the results observed in this study, salmonid growth has been improved using a variety of vertically-suspended structures in numerous experiments [15] [35]-[41]. Rosburg et al. [41] also reported increased growth in similarly-sized landlocked fall Chinook salmon reared with vertically-suspended structure. However, no effects on salmonid growth from suspended structure were observed by White et al. [13], Huysman et al. [53], and Jones et al. [44].

The relatively poor feed conversion ratios observed in the exercised tanks was likely the result of over-feeding. Feeding rates were elevated in the exercise treatments because Parker and Barnes [49] indicated exercise only improved growth if food rations were increased in comparison to unexercised fish. Overall, the feed conversion ratios seen in this study are similar to those reported in other salmonid experiments evaluating exercise [46] [49] [69], vertically-suspended structure [15] [35] [36] [37] [38] [41] [42] [43] [44] [70] [71] [72], or exercise and structure in combination [45] [73]. However, Parker and Barnes [53] and Huysman et al. [39] reported poorer feed conversion ratios in their exercise and structure studies using landlocked fall Chinook salmon.

The lack of significant differences in individual fish lengths and weights is not 
surprising given the small sample sizes [74]. In addition, as is typically observed during the rearing of feral landlocked Chinook salmon at McNenny Hatchery, considerable variation in fish size was also evident and likely affected the ability to detect any significant differences in individual fish metrics [75].

The specific growth rate in this study is higher than that observed with exercised Chinook salmon by Kiessling et al. [54]. However, it is lower than the 4.5\% reported by Huysman et al. [39] for the same strain of landlocked fall Chinook salmon. The salmon used in the Huysman et al. [39] study were smaller than those used in this study, and specific growth rate is affected by the size of the fish [76]. Huysman et al. [39] also reported a condition factor $20 \%$ lower than that reported in this study and by other authors examining Chinook salmon during rearing with exercise [8] [53] [54] or structure [40] [42] [70].

\section{Conclusion}

In conclusion, this study indicates that the use of both an exercise routine and vertically-suspended structure may be beneficial during the rearing of juvenile landlocked fall Chinook salmon. The exact mechanism where-by both exercise and structure are beneficial, while exercise alone is not, has yet to be determined. Additional research should be conducted on other possible benefits resulting from the combination of exercise and structure during the hatchery rearing of Chinook salmon, particularly with the positive effects of environmental enrichment on Chinook salmon stress reduction and post-stocking survival reported by Cogliati et al. [31] and Fast et al. [77]. There is also still a need to determine the ideal swimming speeds and exercise routines for the different sizes of nearly all fish species.

\section{Acknowledgements}

We thank Misty Jones and Lynn Slama for their assistance in this study.

\section{Conflicts of Interest}

The authors declare no conflicts of interest regarding the publication of this paper.

\section{References}

[1] Leon, K.A. (1986) Effect of Exercise on Feed Consumption, Growth, Food Conversion, and Stamina of Brook Trout. The Progressive Fish-Culturist, 48, 43-46. https://doi.org/10.1577/1548-8640(1986)48\%3C43:EOEOFC\%3E2.0.CO;2

[2] Anttila, K., Mänttäri, S. and Järvilehto, M. (2006) Effects of Different Training Protocols on $\mathrm{Ca}^{2+}$ Handling and Oxidative Capacity in Skeletal Muscle of Atlantic Salmon (Salmo salar L.). Journal of Experimental Biology, 209, 2971-2978. https://doi.org/10.1242/jeb.02341

[3] He, W., Xia, W., Cao, Z.-D. and Fu, S.-J. (2013) The Effect of Prolonged Exercise Training on Swimming Performance and the Underlying Biochemical Mechanisms in Juvenile Common Carp (Cyprinus carpio). Comparative Biochemistry and Phy- 
siology, Part A, 166, 308-315. https://doi.org/10.1016/j.cbpa.2013.07.003

[4] Liu, G., Wu, Y., Qin, X., Shi, X. and Wang, X. (2018) The Effect of Aerobic Exercise Training on Growth Performance, Innate Immune Response, and Disease Resistance in Juvenile Schizothorax prenanti. Aquaculture, 486, 18-25. https://doi.org/10.1016/j.aquaculture.2017.12.006

[5] Anttila, K., Jokikokko, E., Erkinaro, J., Järvilehto, M. and Mänttäri, S. (2011) Effects of Training on Functional Variables of Muscles in Reared Atlantic Salmon Salmo salar Smolts: Connection to Downstream Migration Pattern. Journal of Fish Biolo$g y$, 78, 522-566. https://doi.org/10.1111/j.1095-8649.2010.02871.x

[6] Castro, V., Grisdale-Helland, B., Helland, S.J., Kristensen, T., Jørgensen, S.M., Helgerud, J., Claireaux, G., Farrell, A.P., Krasnov, A. and Takle, H. (2011) Aerobic Training Stimulates Growth and Promotes Disease Resistance in Atlantic Salmon (Salmo salar). Comparative Biochemistry and Physiology, Part A, 160, 278-290.

https://doi.org/10.1016/j.cbpa.2011.06.013

[7] Evenson, M.D. and Ewing, R.D. (1993) Effect of Exercise of Juvenile Winter Steelhead on Adult Returns to Cole River Hatchery, Oregon. The Progressive Fish-Culturist, 55, 180-183. https://doi.org/10.1577/1548-8640(1993)055\%3C0180:EOEOJW\%3E2.3.CO;2

[8] Hoffnagle, T.L., Carmichael, R.W. and Keniry, P.J. (2006) The Effect of Moderately Increased and Variable Raceway Flow Rate on Juvenile Physiology, Survival, and Adult Return of Hatchery-reared Chinook Salmon. Transactions of the American Fisheries Society, 135, 1567-1577. https://doi.org/10.1577/T05-246.1

[9] Woodward, J.J. and Smith, L.S. (1985) Exercise Training and the Stress Response in Rainbow Trout, Salmo gairdneri Richardson. Journal of Fish Biology, 26, 435-447. https://doi.org/10.1111/j.1095-8649.1985.tb04283.x

[10] Barrett, B.A. and McKeown, B.A. (1988) Growth Hormone Response to Sustained Swimming in Exercise-Acclimated Steelhead Trout, Salmo gairdneri. Journal of Fish Biology, 32, 799-800. https://doi.org/10.1111/j.1095-8649.1988.tb05421.x

[11] Christiansen, J.S. and Jobling, M. (1990) The Behavior and the Relationship between Food Intake and Growth of Juvenile Arctic Charr, Salvelinus alpinus L., Subjected to Sustained Exercise. Canadian Journal of Zoology, 68, 2185-2191. https://doi.org/10.1139/z90-303

[12] Gallaugher, P.E., Thorarensen, H., Kiessling, A. and Farrell, A.P. (2001) Effects of High Intensity Exercise Training on Cardiovascular Function, Oxygen Uptake, Internal Oxygen Transport and Osmotic Balance in Chinook Salmon (Oncorhynchus tshawytscha) during Critical Speed Swimming. Journal of Experimental Biology, 204, 2861-2872.

[13] Jørgensen, E.H. and Jobling, M. (1993) The Effects of Exercise on Growth, Food Utilisation and Osmoregulatory Capacity of Juvenile Atlantic Salmon, Salmo salar. Aquaculture, 116, 233-246. https://doi.org/10.1016/0044-8486(93)90011-M

[14] Näslund, J. and Johnsson, J.I. (2016) Environmental Enrichment for Fish in Captive Environments: Effects of Physical Structures and Substrates. Fish and Fisheries, 17, 1-30. https://doi.org/10.1111/faf.12088

[15] Kientz, J.L., Crank, K.M. and Barnes, M.E. (2018) Enrichment of Circular Tanks with Vertically Suspended Strings of Colored Balls Improves Rainbow Trout Rearing Performance. North American Journal of Aquaculture, 80, 162-167. https://doi.org/10.1002/naaq.10017

[16] Berejikian, B.A., Tezak, E.P., Flagg, T.A., LaRae, A.L., Kummerow, E. and Mahnken, C.V.W. (2000) Social Dominance, Growth, and Habitat Use of Age-0 Steelhead (On- 
corhynchus mykiss) Grown in Enriched and Conventional Hatchery Rearing Environments. Canadian Journal of Fisheries and Aquatic Sciences, 57, 628-636. https://doi.org/10.1139/f99-288

[17] Maynard, D., Berejikian, B., Flagg, T. and Mahnken, C. (2001) Development of a Natural Rearing System to Improve Supplemental Fish Quality. 1996-1998 Progress Report. United States. National Oceanic and Atmospheric Administration, Silver Spring. https://doi.org/10.2172/789584

[18] Berejikian, B.A. and Tezak, E.P. (2005) Rearing in Enriched Hatchery Tanks Improves Dorsal Fin Quality of Juvenile Steelhead. North American Journal of Aquaculture, 67, 289-293. https://doi.org/10.1577/A05-002.1

[19] Tatara, C.P., Riley, S.C. and Scheurer, J.A. (2008) Environmental Enrichment in Steelhead (Oncorhynchus mykiss) Hatcheries: Field Evaluation of Aggression, Foraging, and Territoriality in Natural and Hatchery Fry. Canadian Journal of Fisheries and Aquatic Sciences, 65, 744-753. https://doi.org/10.1139/f08-004

[20] Watz, J., Calles, O., Carlsson, N., Collin, T., Huusko, A., Johnsson, J., Nilsson, P.A., Norrgård, J. and Nyqvist, D. (2019) Wood Addition in the Hatchery and River Environments Affects Post-Release Performance of Overwintering Brown Trout. Freshwater Biology, 64, 71-80. https://doi.org/10.1111/fwb.13195

[21] Bosakowski, T. and Wagner, E.J. (1995) Experimental Use of Cobble Substrates in Concrete Raceways for Improving Fin Condition of Cutthroat (Oncorhynchus clarki) and Rainbow Trout (O. mykiss). Aquaculture, 130, 159-165. https://doi.org/10.1016/0044-8486(94)00223-B

[22] Salvanes, A.G.V., Moberg, O., Ebberson, L.O.E., Nilsen, T.O., Jensen, K.H. and Braithwaite, V.A. (2013) Environmental Enrichment Promotes Neural Plasticity and Cognitive Ability in Fish. Proceedings of the Royal Society B, 280, Article ID: 20131331. https://doi.org/10.1098/rspb.2013.1331

[23] Jonsson, B. and Jonsson, N. (2014) Early Environment Influences Later Performance in Fishes. Journal of Fish Biology, 85, 151-188. https://doi.org/10.1111/jfb.12432

[24] Lee, J.S.F. and Berejikian, B.A. (2008) Effects of the Rearing Environment on Average Beavhiour and Behavioural Variation in Steelhead. Journal of Fish Biology, 72, 1736-1749. https://doi.org/10.1111/j.1095-8649.2008.01848.x

[25] Strand, D.A., Utne-Palm, A.C., Jakobsen, P.J., Braithwaite, V.A., Jensen, K.H. and Salvanes, A.G.V. (2010) Enrichment Promotes Learning in Fish. Marine Ecology Progress Series, 412, 273-282. https://doi.org/10.3354/meps08682

[26] Näslund, J., Rosengren, M., Del Villar, D., Gansel, L., Norrgård, J.R., Persson, L., Winkowski, J.J. and Kvingedal, E. (2013) Hatchery Tank Enrichment Affects Cortisol Levels and Shelter-Seeking in Atlantic Salmon (Salmo salar). Canadian Journal of Fisheries and Aquatic Sciences, 70, 585-590. https://doi.org/10.1139/cjfas-2012-0302

[27] Bergendahl, I.A., Miller, S., Depasquale, C., Giralico, L. and Braithwaite, V.A. (2016) Becoming a Better Swimmer: Structural Complexity Enhances Agility in CaptiveReared Fish. Journal of Biology, 90, 1112-1117. https://doi.org/10.1111/jfb.13232

[28] Self, K.E., Schreck, C.B., Cogliati, K.M., Billman, E.J. and Noakes, D.L.G. (2018) The Effect of Rearing Structures on Behaviour and Movement of Juvenile Steelhead Oncorhynchus mykiss. Journal of Fish Biology, 93, 449-454.

https://doi.org/10.1111/jfb.13657

[29] Krebs, J., Crank, K.M., Krebs, E. and Barnes, M.E. (2017) Use of Bottom Structure and Tank Cover during Rainbow Trout Rearing in Circular Tanks. Journal of Fish 
Fisheries and Livestock Production, 5, 247. https://doi.org/10.4172/2332-2608.1000247

[30] Bergendahl, I. A., Salvanes, A.G.V. and Braithwaite, V.A. (2016) Determining the Effects of Duration and Recency of Exposure to Environmental Enrichment. Applied Animal Behavaiour Science, 176, 163-169. https://doi.org/10.1016/j.applanim.2015.11.002

[31] Cogliati, K.M., Herron, C.L., Noakes, D.L.G. and Schreck, C.B. (2019) Reduced Stress Response in Juvenile Chinook Salmon Reared with Structure. Aquaculture, 504, 96-101. https://doi.org/10.1016/j.aquaculture.2019.01.056

[32] Rahman, M.M., Nur, N., Hasan, M.M.-A., Asaduzzaman, S., Rouf, M.A. and Rahman, S.M. (2020) Effects of Light and Artificial Fish Shelter (PVC) on Some Phenotypic Traits of Stinging Catfish (Heteropneustes fossilis Bloch, 1794). Aquaculture Research, 51, 124-134. https://doi.org/10.1111/are.14354

[33] Baynes, S.M. and Howell, B.R. (1993) Observations on the Growth, Survival and Disease Resistance of Juvenile Common Sole, Solea solea (L.), Fed Mytilus edulis L. Aquaculture Research, 24, 95-100. https://doi.org/10.1111/j.1365-2109.1993.tb00831.x

[34] Tuckey, L.M. and Smith, T.I.J. (2001) Effects of Photoperiod and Substrate on Larval Development and Substrate Preference of Juvenile Southern Flounder, Paralichthys lethostigma. Journal of Applied Aquaculture, 11, 1-20. https://doi.org/10.1300/J028v11n01 02

[35] Kientz, J.L. and Barnes, M.E. (2016) Structural Complexity Improves the Rearing Performance of Rainbow Trout in Circular Tanks. North American Journal of Aquaculture, 78, 203-207. https://doi.org/10.1080/15222055.2016.1159629

[36] Krebs, E., Huysman, N., Voorhees, J.M. and Barnes, M.E. (2018) Suspended Arrays Improve Rainbow Trout Growth during Hatchery Rearing in Circular Tanks. International Journal of Aquaculture and Fishery Science, 4, 27-30.

[37] Crank, K.M., Kientz, J.L. and Barnes, M.E. (2019) An Evaluation of Vertically Suspended Environmental Enrichment Structures during Rainbow Trout Rearing. North American Journal of Aquaculture, 81, 94-100. https://doi.org/10.1002/naaq.10064

[38] Huysman, N., Krebs, E., Voorhees. J.M. and Barnes, M.E. (2019) Use of Two Vertically-suspended Environmental Enrichment Arrays during Rainbow Trout Rearing in Circular Tanks. International Journal of Innovative Studies in Aquatic Biology and Fisheries, 5, 25-30. https://doi.org/10.20431/2454-7670.0501005

[39] Huysman, N., Voorhees, J.M., Krebs, E. and Barnes, M.E. (2020) Vertically-Suspended Environmental Enrichment Improves Growth of Landlocked Fall Chinook Salmon during Initial Hatchery Rearing. Open Journal of Applied Sciences, 10, 725 731. https://doi.org/10.4236/ojapps.2020.1011051

[40] Rosburg, A.J., Fletcher, B.L., Barnes, M.E., Treft, C.E. and Bursell, B.R. (2019) Vertically-Suspended Environmental Enrichment Structures Improve the Growth of Juvenile Landlocked Fall Chinook Salmon. International Journal of Innovative Studies in Aquatic Biology and Fisheries, 5, 17-24. https://doi.org/10.20431/2454-7670.0501004

[41] White, S.C., Krebs, E., Huysman, N., Voorhees, J.M. and Barnes, M.E. (2019) Use of Suspended Plastic Conduit Arrays during Brown Trout and Rainbow Trout Rearing in Circular Tanks. North American Journal of Aquaculture, 81, 101-106. https://doi.org/10.1002/naaq.10076

[42] White, S.C., Barnes, M.E., Krebs, E., Huysman, N. and Voorhees, J.M. (2018) Addition of Vertical Enrichment Structures Does Not Improve Growth of Three Salmo- 
nid Species during Hatchery Rearing. Journal of Marine Biology and Aquaculture, 4, 48-52. https://doi.org/10.15436/2381-0750.18.1957

[43] Huysman, N., Kreb, E., Voorhees, J.M. and Barnes, M.E. (2019) Use of Large Vertically-Suspended Rod Array in Circular Tanks during Juvenile Rainbow Trout Rearing. International Journal of Marine Biology and Research, 4, 1-5.

[44] Jones, M.D., Krebs, E., Huysman, N., Voorhees, J.M. and Barnes, M.E. (2019) Rearing Performance of Atlantic Salmon Grown in Circular Tanks with Vertically-Suspended Environmental Enrichment. Open Journal of Animal Sciences, 9, 249-257. https://doi.org/10.4236/ojas.2019.92021

[45] Voorhees, J.M., Huysman, N., Krebs, E. and Barnes, M.E. (2020) Influence of Water Velocity and Vertically-suspended Structures on Rainbow Trout Rearing Performance. Open Journal of Animal Sciences, 10, 152-161.

https://doi.org/10.4236/ojas.2020.101008

[46] Voorhees, J.M., Huysman, N., Krebs, E. and Barnes, M.E. (2020) Impacts of Different Exercise Routines on Rainbow Trout Rearing Performance. Journal of Fisheries Sciences.com, 14, 8-13.

[47] Walker, L.M., Parker, T.M. and Barnes, M.E. (2016) Full and Partial Overhead Tank Cover Improves Rainbow Trout Rearing Performance. North American Journal of Aquaculture, 78, 20-24. https://doi.org/10.1080/15222055.2015.1090504

[48] Buterbaugh, G.L. and Willoughby, H. (1967) A Feeding Guide for Brook, Brown, and Rainbow Trout. The Progressive Fish-Culturist, 29, 210-215.

https://doi.org/10.1577/1548-8640(1967)29[210:AFGFBB]2.0.CO;2

[49] Parker, T.M. and Barnes, M.E. (2015) Effects of Different Water Velocities on the Hatchery Rearing Performance and Recovery from Transportation of Rainbow Trout Fed Two Different Rations. Transactions of the American Fisheries Society, 144, 882890. https://doi.org/10.1080/00028487.2015.1047533

[50] Voorhees, J.M., Barnes, M.E., Chipps, S.R. and Brown, M.L. (2018) Rearing Performance of Juvenile Brown Trout (Salmo trutta) Subjected to Exercise and Dietary Bioprocessed Soybean Meal. Open Journal of Animal Science, 8, 303-308.

https://doi.org/10.4236/ojas.2018.83023

[51] Voorhees, J.M., Barnes, M.E., Chipps, S.R. and Brown, M.L. (2019) Effects of Exercise and Bioprocessed Soybean Meal Diets during Rainbow Trout Rearing. The Open Biology Journal, 7, 1-13. https://doi.org/10.2174/1874196701907010001

[52] Davison, W. (1997) The Effects of Exercise Training on Teleost Fish, a Review of Recent Literature. Comparative Biochemistry and Physiology Part A: Physiology, 117, 67-75. https://doi.org/10.1016/S0300-9629(96)00284-8

[53] Parker, T.M. and Barnes, M.E. (2014) Rearing Velocity Impacts on Landlocked Fall Chinook Salmon (Oncorhynchus tsawytscha) Growth, Condition, and Survival. Open Journal of Animal Sciences, 4, 244-252. https://doi.org/10.4236/ojas.2014.45031

[54] Kiessling, A., Higgs, D.A., Dosanjh, B.S. and Eales, J.G. (1994) Influence of Sustained Exercise at Two Ration Levels on Growth and Thyroid Function of All-Female Chinook Salmon (Oncorhynchus tshawytscha) in Seawater. Canadian Journal of Fisheries and Aquatic Sciences, 51, 1975-1984. https://doi.org/10.1139/f94-200

[55] Davison, W. and Goldspink, G. (1977) The Effect of Prolonged Exercise on the Lateral Musculature of the Brown Trout (Salmo trutta). Journal of Experimental Biology, 70, 1-12.

[56] Christiansen, J.S., Ringø, E. and Jobling, M. (1989) Effects of Sustained Exercise on Growth and Body Composition of First-Feeding Fry of Arctic Charr, Salvelinus alpinus (L.). Aquaculture, 79, 329-335. https://doi.org/10.1016/0044-8486(89)90474-2 
[57] Farrell, A.P., Johansen, J.A., Steffensen, J.F., Moyes, C.D., West, T.G. and Suarez, R.K. (1990) Effects of Exercise Training and Coronary Ablation on Swimming Performance, Heart Size, and Cardiac Enzymes in Rainbow Trout, Oncorhynchus mykiss. Canadian Journal of Zoology, 68, 1174-1179. https://doi.org/10.1139/z90-174

[58] Good, C., May, T., Crouse, C., Summerfelt, S. and Welch, T.J. (2016) Assessing the Impacts of Swimming Exercise and the Relative Susceptibility of Rainbow Trout Oncorhynchus mykiss (Walbaum) and Atlantic Salmon Salmo salar L. Following Injection Challenge with Weissella ceti. Journal of Fish Diseases, 39, 1387-1391. https://doi.org/10.1111/jfd.12468

[59] Fenkes, M., Shiels, H.A. and Nudds, R.L. (2017) Body Shape and Robustness Response to Water Flow during Development of Brown Trout Salmo trutta Parr. Journal of Fish Biology, 93, 360-369. https://doi.org/10.1111/jfb.13772

[60] Voorhees, J.M., Barnes, M.E., Chipps, S.R. and Brown, M.L. (2018) Dietary Bioprocessed Soybean Meal Does Not Affect the Growth of Exercised Juvenile Rainbow Trout (Oncorhynchus mykiss). Journal of Animal Research and Nutrition, 3, 6.

[61] Waldrop, T., Summerfelt, S., Mazik, P. and Good, C. (2018) The Effects of Swimming Exercise and Dissolved Oxygen on Growth Performance, Fin Condition and Precocious Maturation of Early-Rearing Atlantic Salmon Salmo salar. Aquaculture Research, 49, 801-808. https://doi.org/10.1111/are.13511

[62] Flagg, T.A., Prentice, E.F. and Smith, L.S. (1983) Swimming Stamina and Survival Following Direct Seawater Entry during Parr-Smolt Transformation of Coho Salmon (Oncorhynchus kisutch). Aquaculture, 32, 383-396. https://doi.org/10.1016/0044-8486(83)90235-1

[63] Houlihan, D.F. and Laurent, P. (1987) Effects of Exercise Training on the Performance, Growth, and Protein Turnover of Rainbow Trout (Salmo gairdneri). Canadian Journal of Fisheries and Aquatic Science, 44, 1614-1621. https://doi.org/10.1139/f87-195

[64] McKenzie, D.J., Palstra, A.P., Planas, J., MacKenzie, S., Bégout, M.-L., Thorarensen, H., Vandeputte, M., Mes, D., Rey, S., De Boeck, G. and Domenici, P. (2020) Aerobic Swimming in Intensive Finfish Aquaculture: Applications for Production, Mitigation and Selection. Reviews in Aquaculture, 13, 138-155.

https://doi.org/10.1111/raq.12467

[65] Moine, J., Barnes, M.E., Kientz, J. and Simpson, G. (2016) Flow Pattern in Circular Rearing Tanks Containing Vertical Structure. Journal of Fisheries and Livestock Production, 4, Article No. 204.

[66] Muggli, A.M., Barnes, J.M. and Barnes, M.E. (2019) Vertically-suspended Environmental Enrichment Alters the Velocity Profiles of Circular Fish Rearing Tanks. World Journal of Engineering and Technology, 7, 208-226. https://doi.org/10.4236/wjet.2019.71014

[67] Caasi, J.M.A., Barnes, J.M. and Barnes, M.E. (2020) Impact of Vertically-suspended Environmental Enrichment and Two Densities of Fish on Circular Tank Velocity Profiles. Engineering, 12, 723-738. https://doi.org/10.4236/eng.2020.1210051

[68] Gorle, J.M.R., Terjesen, B.F., Mota, V.C. and Summerfelt, S. (2018) Water Velocity in Commercial RAS Culture Tanks for Atlantic Salmon Smolt Production. Aquaculture Engineering, 81, 89-100. https://doi.org/10.1016/j.aquaeng.2018.03.001

[69] Morris, B., Voorhees., J.M., Huysman, N., Krebs, E. and Barnes, M.E. (2020) Effects of Intermittent Exercise during Initial Rainbow Trout Oncorhynchus mykiss Rearing in Tanks Containing Vertically-Suspended Environmental Enrichment. Aquaculture and Fisheries Studies, 2, 1-4. https://doi.org/10.31038/AFS.2020225 
[70] Jones, M.D., Voorhees, J.M., Huysman, N., Krebs, E. and Barnes, M.E. (2020) Use of Different Colours of Vertically-suspended Structure during the Hatchery Rearing of Juvenile Landlocked Fall Chinook Salmon (Oncorhynchus tshawytscha, Walbaum). International Journal of Fisheries and Aquaculture, 12, 21-25. https://doi.org/10.5897/IJFA2019.0762

[71] Chapman, A., Huysman, N., Voorhees, J.M., Krebs, E. and Barnes, M.E. (2020) Color and Vertically-Suspended Environmental Enrichment Does Not Effect Juvenile Rainbow Trout Growth during Hatchery Rearing. International Journal of Fisheries and Aquatic Sciences, 8, 32-36.

[72] Meza, E., Jones, M.D., Huysman, N., Voorhees, J.M. and Barnes, M.E. (2020) Color of Vertically-Suspended Structure Does Not Impact the Growth of Rainbow Trout Reared in Circular Tanks. Open Journal of Animal Sciences, 10, 706-713. https://doi.org/10.4236/ojas.2020.104045

[73] Voorhees, J.M., Huysman, N., Krebs, E. and Barnes, M.E. (2020) Use of Exercise and Structure during Rainbow Trout Rearing. Open Journal of Applied Sciences, 10, 258-269. https://doi.org/10.4236/ojapps.2020.105020

[74] Hackshaw, A. (2008) Small Studies: Strengths and Limitations. European Respiratory Journal, 32, 1141-1143. https://doi.org/10.1183/09031936.00136408

[75] Ott, L. (1984) An Introduction to Statistical Methods and Data Analysis. PWS Publishers, Boston.

[76] Hopkins, K.D. (1992) Reporting Fish Growth: A Review of the Basics. Journal of World Aquaculture Society, 23, 173-179. https://doi.org/10.1111/j.1749-7345.1992.tb00766.x

[77] Fast, D.E., Neeley, D., Lind, D.T., Johnston, M.V., Strom, C.R., Bosch, W.J., Knudsen, C.M., Schroder, S.L. and Watson, B.D. (2008) Survival Comparison of Spring Chinook Salmon Reared in a Production Hatchery Under Optimum Conventional and Seminatural Conditions. Transactions of the American Fisheries Society, 137, 1507-1518. https://doi.org/10.1577/T07-143.1 